PETRA BÁRD*

\title{
The German Anti-Discrimination Legislation with a Special Focus on Disability
}

\begin{abstract}
The present essay discusses the recently adopted Act on Anti-Discrimination and the current and future system of disability rights protection mechanisms in the Federal Republic of Germany.

Partly as a response to the atrocities of World War II, partly as a return to pre-war period, both East- and West-Germany adopted extensive disability-related protection mechanisms. The laws currently in force are following this tradition making the system of German disability rights one of the most progressive in Europe. Several pieces of legislation ensure rehabilitation and participation of disabled persons, moreover Germany's constitution has been amended, so that disability is included among the prohibited grounds of the clause on non-discrimination.

Most recently, Germany should have implemented the European Union's Framework Directive the scope of which extends to the prohibition of discrimination on grounds of disability in employment matters. Germany, traditionally so cautious about human rights issues, transposed the Directive with a two-year-delay. The paper scrutinizes the implementing national law and explores the reasons for its numerous failures and the way towards adoption. Various legal and constitutional issues, among others on third party effect, freedom and equality had been brought up in the debate around transposition that had not been addressed at the time the German disability-related laws had been adopted.

The study of these controversies around implementation of the EU Directive is a unique opportunity to shed some light on the underlying constitutional issues of anti-discrimination laws-not only in Germany, but in all Member States of the Union which implemented the Directive without any public, political or legal debates.
\end{abstract}

Keywords: disability, Germany, anti-discrimination, equality, third party effect, supremacy of EC law

In Germany political and religious considerations concerning the care for disabled persons can be traced back to the $15^{\text {th }}$ century. The roots of contemporary German disability-related legislation are rooted in Bismarck's social security system and in the idea to protect war veterans. This post-war protection has been extended to more and more disabled persons until a general approach has been adopted: disability rights as we know them today, are guaranteed irrespectively of the

* SJD Candidate at the Central European University, Legal Studies Department, H1051 Budapest, Nádor u. 9.

E-mail: bardp@ceu.hu 
cause of disability. During the horrors of World War II many disabled individuals became victims of the Nazi ideology. Partly as a response to these atrocities, partly as a return to pre-war period, both East- and West-Germany adopted extensive disability-related protection mechanisms. The laws now in force are following this tradition making the system of German disability rights one of the most progressive one in Europe. A single title of the Social Code is devoted to the rights of disabled persons, ${ }^{1}$ while the general equality of disabled is ensured by a separate act. ${ }^{2}$ The Basic Law, Germany's constitution has been amended, so that disability is included among the prohibited grounds of the clause on non-discrimination. ${ }^{3}$ Most recently, Germany should have implemented the European Union's Framework Directive the scope of which extends to the prohibition of discrimination on grounds of disability in employment matters. After having scrutinized the German pieces of legislation, one can conclude that as to disability-and here I refer to disability only, and I am not dealing with other protected grounds listed in the EU piece of legislation, such as religion, belief, age or sexual orientation-the Directive has almost been implemented in its entirety. Nevertheless, it is worth looking at the implementing national bill and discuss its failure, since many legal and constitutional issues are brought up that had not been discussed at the time the German disability-related laws had been adopted. The study of the controversies may shed some light on the underlying constitutional issues-not only in Germany, but in all Member States of the Union which implemented the Directive without any public, political or legal debates.

The anti-discrimination law raises the same issue as the EU Directive: is it conceivable to regulate discriminations on the basis of the different characteristics in a single piece of legislation? The EU differentiates somewhat between the prohibited grounds, but the degree of protection came closer in recent years. The free movement rights presuppose that there is no differentiation whatsoever on grounds of nationality. Whereas previously gender seemed to follow nationality among the most protected characteristics, now race and ethnicity are said to replace the leading role of gender. At the bottom of the hierarchy are the characteristics listed in the Framework Directive, which only extends to

1 Title IX of the Social Code (Sozialgesetzbuch IX) on the Rehabilitation and Participation of Disabled People entered into force on July 1, 2001.

2 The Equal Opportunities for People with Disabilities Act (Behindertengleichstellungsgesetz) entered into force on May 1, 2002.

3 Article 3 Section (3) has been amended by Sentence [2] in 1994: "Persons may not be discriminated against because of their disability." 
employment matters. The German implementing legislation is comprehensive, since it incorporates the prohibited grounds listed in the diverse Directives. Since however the nature of discrimination based on different grounds are entirely different, the rules cannot take the different needs into account, they are necessarily general. Whereas for example differentiation on the basis of sexual orientation is in most of the cases a result of unjustified negative attitudes against gays and lesbians, discriminations on the basis of disability may serve a legitimate objective and might be permissible. As to disabled individuals, the German solution is beneficial, since the protection of disabled persons is detailed and tailor made in federal laws other than the anti-discrimination law.

The theoretical issues at the heart of the German debate touch the boundaries of the third party effect. The EU pieces of laws have been adopted without any further considerations on the horizontal effect of the Directive: it applies to both public and private entities, i.e. it is also applicable for relations between private persons. In the European Union states can either make difference in the implementing legislation, or the distinction to make is left to the judiciary. According to the German tradition justices decide on the horizontality of basic rights and also on equality. In the disability-related part of the Social Code, just like the draft implementing law the legislators decided on the matter by excluding the judiciary. The horizontality of basic rights is said to limit individual freedom, therefore the controversy whether equality and freedom are mutually exclusive will also be addressed.

The German legislation combines a substantive equality-based approach, both striving to achieve equality of opportunities, equality of result, and a social rights based approach. Social assistance however depends on the income, it can only be granted to the needy. In the current disability discourse there is less emphasis on social rights, which corresponds to the shift from the medical to the social model of disability. The medical model located the problem in the disabled individual, whereas the social "concept indicated the close connection between the limitation experienced by individuals with disabilities, the design and structure of their environments and the attitude of the general population." Whereas the medical model calls for social benefits, the social concept intends to modify the environment and to integrate disabled persons, therefore the emphasis on the equality concept. Despite the claimed adherence to the social model, the medical model heavily influences the German legislation, especially

${ }^{4}$ United Nations Standard Rules on the Equalization of Opportunities for Persons with Disabilities. 
when it comes to the definition of disability and the determination of the degree of impairment.

In the following I will discuss the legal and political considerations behind the German law implementing the EU anti-discrimination Directives. In the first part of the paper I summarize the European imperatives in the filed of equality that are applicable to people living with disabilities; in the second and third parts I will give an insight into the German attempts to comply with the European imperatives. In the fourth part of the present essay I summarize the theoretical considerations that might have prevented the German law from being adopted, such as the consequences of a hierarchy of equality, the effects of Drittwirkung, and the underlying clashes between freedom and equality. In the fifth part of the paper I will address the legal consequences of non-implementation, whereas in the conclusion I engage in forcasting the future of the German anti-discrimination legislation.

\section{European Imperatives}

A Council Directive of 2004, one of 2002 and two Council Directives of 2000 address the issue of discrimination at EU level. Council Directive 2004/113/EC implemented the principle of equal treatment between men and women in the access to and supply of goods and services (hereinafter referred to as the "Gender Goods and Services Directive"), Directive 2002/73/EC amended Directive 76/207/EEC on equal pay for equal work for women and men in employment matters (hereinafter referred to as the "Gender Directive"). Council Directive 2000/43/EC of June 29, 2000, implementing the principle of equal treatment between persons irrespective of racial or ethnic origin (hereinafter referred to as the "Race Directive") and the Council Directive 2000/78/EC of 27 November 2000 establishing a general framework for equal treatment in employment and occupation (hereinafter referred to as the "Framework Directive") both deal with non-discrimination measures. The latter lists disability as a prohibited ground on the basis of which direct or indirect discrimination, instruction to discriminate or harassment are impermissible. All Member States should have implemented the Directive by May 1, 2004. As of September 2005 Germany and Luxemburg, furthermore Austria at regional level, and in respect of Finland, the Åland Islands failed to transpose the Directives. ${ }^{5}$ The German government

5 Cormack, J.-Bell, M.: Developing Anti-Discrimination Law in Europe: The 25 EU Member States compared. Belgium and the Netherlands, 2005. 13. 
was striving to transpose the EU laws, however failed to adopt the Act which would have implemented the EU Directive's provisions. The German Bundesländer, which should also implement the law, are waiting for the federal legislator to act.

The EU Directives set the basic principles and the framework rules, and following from the nature of a Directive, set the objectives each Member State should achieve individually through implementation. The Directives leave wide discretion to the Member States as to transposition. Apart from non-implementation, several other kinds of national approaches can be traced. Some Member States incompletely transpose the Directives picking the elements they prefer and excluding those that are controversial in their society. Others copy the Directives word by word into their national law, which is problematic, since the details are deliberately left to the individual Member States by the EU Directives; failing to regulate these details leaves an unjustifiably wide responsibility to the courts in interpreting the vague provisions. Finally, there are states that went beyond the prerequisites of EU law and afforded greater protection to the covered groups than necessary according to the acquis communautaire. ${ }^{6}$

\section{German Implementation}

Towards the end of 2001 the parliamentary factions of SPD (German Social Democratic Party) and BÜNDNIS 90/DIE GRÜNEN (Green Party) drafted a law which would have implemented the gender-related and Race and the Framework Directives together in a comprehensive way. This corresponded to Point IX.10. of the Coalition Agreement of October 20, 1998. ${ }^{7}$ In its first

\footnotetext{
${ }^{6}$ Mark Bell differentiates between five possible approaches on the side of Member States: non-implementation, incomplete implementation, incorrect implementation, paper implementation, and innovation and implementation. Presentation at a seminar conducted in the framework of the Community Action Programme to Combat Discrimination: The Fight Against Discrimination: The Equal Treatment Directives of 2000. Trier, 28-29 November 2005.

7 "Die neue Bundesregierung will Minderheiten schützen und ihre Gleichberechtigung und gesellschaftliche Teilhabe erreichen. Niemand darf wegen seiner Behinderung, Herkunft, Hautfarbe, ethnischer Zugehörigkeit oder sexueller Orientierung als Schwuler oder Lesbe diskriminiert werden. Dazu werden wir ein Gesetz gegen Diskriminierung und zur Förderung der Gleichbehandlung (u.a. mit der Einführung des Rechtsinstituts der eingetragenen Lebenspartnerschaft mit Rechten und Pflichten) auf den Weg bringen. Die Empfehlungen des Europäischen Parlaments zur Gleichberechtigung von Lesben und Schwulen werden
} 
official form, Herta Däubler-Gmelin, then Minister of Justice presented the draft law. The proposal was however much broader in scope than the EU Directives would have required. Comparing the scope of the Race and Framework Directives it becomes visible that the former is much broader. Sometimes this notion is referred to as the "hierarchy of equality". ${ }^{8}$ In gender issues there are a great number of pieces of legislation to achieve equal treatment and an extensive case-law of the European Court of Justice is backing it up. As to race an ethnicity the scope of protection is still wide, however less broad than in case of sex. Finally the characteristics listed in the Framework Directive since the document's entry into force also enjoy some protection against discrimination, however the material scope of the law is narrower, and a number of explicit exceptions are granted. The EU Directives require implementation in the field of general contract law as regards discrimination on the basis of sex, race and ethnic origin. As to the other grounds, implementation is only necessary in employment and related fields, such as vocational training and education.

The result of a common implementation of the pieces of EU legislation was that the drafters elevated the level of protection as regards religion, belief, disability, age and sexual orientation regulated by the Framework Directive to contracts, to the supply of goods and services offered to the public, i.e. to the level of protection granted by the Race and Gender Directives, which are way beyond the scope of the former.

The first draft of the German law intended to insert a new subtitle, Subtitle 5 to Section 3 Title 1 BGB on the creation, subject matter and termination of contractual obligations [Articles 319 a)-e)]. Article 319 a) would have prohibited any discrimination based on race, ethnic origin, sex, religion or belief, sexual identity, age or disability in the conclusion, content or termination of a contract offered to the public concluded in the field of occupation, education or health-

berücksichtigt.” [,The new Federal Government wants to protect minorities and to achieve their equal rights and social participation. Nobody may be discriminated against on the basis of his or her disability, origin, skin color, ethnic origin or sexual orientation as gay or a lesbian. In addition we will draft a law against discrimination and for the promotion of equal treatment (among others with the introduction of the legal notion of registered life partnership that encompasses rights and obligations). The recommendations of the European Parliament regarding the equal rights of lesbians and gays will be considered."] http://www.datenschutz-berlin.de/doc/de/koalo/09.htm\#ix10

${ }^{8}$ E.g. Waddington, L.: The new equality Directives - mixed blessings, in Costello, C.-Barry, E. (Eds.): Equality in Diversity, The New Equality Directives. Dublin, 2003. 3954; Borillo, D.: Lutter contre les discriminations. Paris, 2003. 
care. The prerequisite "offered to the public" means that the rule has to extend beyond private relations. With the Framework Directive in line, Articles 319 a) and $319 \mathrm{~b}$ ) prohibited any direct or indirect discrimination, harassment or instruction to discriminate. Article 319 d) dealt with exclusively private relations (with the exception of labor law). It took account of the fact that the ban on discrimination cannot be as absolute as in case of public contracts. It allowed for the balancing of private interests to some extent, and as an exception allowed for discrimination in case of certain professions. An explicit exception referred to age and disability in case there was a genuine and determinative occupational requirement that prevented handicapped persons, or people under or above a certain age to take the job. Further, according to the draft discrimination did not occur, if there is a reasonable purpose (sachlicher Grund) for the differential treatment of persons having the listed characteristics. Such reasonable purposes relevant for disabled persons were especially the avoidance of dangers, prevention of damage or other purposes of comparable kind; the protection of privacy or personal security; if different treatment was designed to grant special advantages and an interest in the penetration of equal treatment was missing; and finally in case of private insurance companies' statistical risk evaluation (however, here potential pregnancy is excluded as a justifiable reason for differentiation). In line with the Framework Directive and similarly to Article 611 Section (1) $\mathrm{BGB}$ on the prohibition of gender-based discrimination in case of employment contracts, the new Article 319 c) allowed for the partial reversal of the burden of proof with the aim to enhance discriminated persons' chances to litigate a case. According to this provision the persons protected only had to make the facts which indicated that discrimination had occurred, plausible (glaubhaft machen). The other party to the case was to bear the burden of proving that his or her decision, action had been unrelated to the applicant's protected characteristic. The opponents of the modification argued that negative evidence, in this case the lack of discriminatory intentions, is very difficult to be proven. ${ }^{9}$ Indeed, this criticism has been voiced in relation to the mentioned EU Directive as well. An employer has to use objective tests when interviewing applicants for a position, and he or she can only take the job-related characteristics into account. However, in order to prove at a possible later litigation that no discrimination occurred, employers first have to ask questions in writing, or record an oral interview and second, they must keep these documents and

9 Ladeur, K.-H.: The German Proposal of an „Anti-Discrimination”-Law: Anticonstitutional and Anti-Common Sense. A Response to Nicola Vennemann. German Law Journal, 2002. 
records so as to be able to prove at a later point in time that a rejected applicant has not been discriminated against. This might be especially burdensome for smaller companies where the method of interviewing is rather informal, oral and where the recording and storing of data is problematic. It has also been pointed out that these procedural rules "only touch the stupid", ${ }^{10}$ as it is fairly easy to overcome the provisions and to use more sophisticated filters for screening out disabled, if someone really intends to do so. It has been predicted that employers will find a way out from the legal obligations, and the whole legal system will be weakened by this forced dishonesty. ${ }^{11}$ Again others reminded to the disadvantages in living under a permanent threat for being suspicious of discriminatory behavior. Once the fact of discrimination has been established, it may have two kinds of consequences according to Article 319 e). First, whenever relevant, the court may oblige the discriminator to refrain from such behavior in the future, and second the court may order the employer to treat the applicant in a non-discriminating manner and to undo the consequences of discrimination. (Folgenbeseitigungsanspruch) This can also lead to the modification of the employment contract. Should the employer already have concluded a contract with someone by the time the discrimination has been proven, this contract cannot be contested, but instead compensation can be asked. ${ }^{12}$ The same rule applies in case of one-time occasions. ${ }^{13}$ The new rules on granting the possibility for associations and other legal persons to represent discriminated individuals reflected Article 9 of the Framework Directive. Victims of discrimination could have assigned their claims for compensation to associations. These NGOs would have had the possibility to represent persons discriminated in court proceedings, where representation was allowed by persons other than attorneys. The procedural rules have partially repeated the wording of Article 63 SGB IX extending this rule to discrimination based on other grounds as well. A difference in the Verbandsklagerecht regulated by SGB IX and the proposed anti-discrimination act is that the latter allowed for representation of the discriminated person, even in lack of his or her authorization. It has been criticized as being a too far reaching position, driven by the "impulse to fulfill

\footnotetext{
${ }^{10}$ Ibid.

${ }^{11}$ Picker, E.: Anti-Discrimination as a Program of Private Law? German Law Journal, 2003. 778; Ladeur: op. cit. 9.

${ }^{12}$ The compensation requirement is also subject to many criticisms, because of the high possibility of abuse. See e.g. Picker: op. cit. 776.

${ }^{13}$ Vennemann, N.: The German Draft Legislation on the Prevention of Discrimination in the Private Sector. German Law Journal, 2002.
} 
a German 'Übersoll', ${ }^{14}$ however technically it is difficult to imagine a scenario where a legal person litigates against the injured party's will without his or her cooperation. In the rare cases when it happens however, associations should consider whether bringing a case to the court in the absence of the victim's wish would be beneficial or detrimental for him or her. As to discrimination based on disability, the SGB IX as lex specialis compared to the proposed antidiscrimination legislation, would prevail over the latter.

The bill has been redrafted several times until the Bundestag adopted it on June 17, 2005. The Bundesrat voted against the law on July 8, 2005 with the argument that the proposed act was unreasonably wide, and violated private autonomy. ${ }^{15}$ The issue was promised to be brought up again in the new, $16^{\text {th }}$ election period. The coalitions agreement between the SPD and CDU/CSU took the implementation of the anti-discrimination Directives for granted despite all disagreements. ${ }^{16}$

The initial draft has been changed both in structure and in content. Whereas the first version intended to amend the $\mathrm{BGB}$, the later bill was drafted as a separate federal act initially named Act on Anti-discrimination [(Gesetz zum Schutz vor Diskriminierung (Antidiskriminierungsgesetz, $A D G)] .{ }^{17}$ In the last version of the bill the title has been changed to General Equal Treatment Act (Allgemeine Gleichbehandlungsgesetz, AGG). Finally, the act has been adopted in August, 2006. The aim of the law is to prevent or eliminate negative discrimination (Benachteiligung) on the basis of race, ethnic origin, sex, religion or belief, disability, age or sexual identity. ${ }^{18}$ The German legislature adopted parallelly a separate law on anti-discrimination of soldiers. (Gesetz zum Schutz der Soldatinnen und Soldaten vor Diskriminierung, SADG)

In the meanwhile since the first steps of the implementation process, two more laws have been adopted by the EU legislators, so the recent versions of

${ }^{14}$ Picker: op. cit. 776.

${ }^{15}$ Unterrichtung durch den Bundesrat Gesetz zur Umsetzung europäischer Antidiskriminierungsrichtlinien: Anrufung des Vermittlungsausschusses - Drucksachen 15/4538, $15 / 5717$.

${ }^{16}$ Die EU-Gleichbehandlungsrichtlinien werden in deutsches Recht umgesetzt. [The EU Equal Treatment Directives will be implemented into German law.] Point 2.3. of Title VII. The Agreement mentions the social laws in favor of disabled persons, their social participation and the need for the promotion of parasport. http://koalitionsvertrag.spd. de/servlet/PB/show/1645854/111105_Koalitionsvertrag.pdf

${ }^{17}$ Gesetzentwurf Drucksache 15/4538 Deutscher Bundestag, December 16, 2004. http://dip.bundestag.de/btd/15/045/1504538.pdf

${ }^{18}$ Article 1 AGG. 
both the general anti-discrimination law and its twin sister, the law protecting soldiers transplant the Gender Goods and Services Directive, the Gender Directive, the Race Directive and the Framework Directive.

The scope of this general anti-discrimination law is, similarly to the previous one, much wider than the EU Directives would have required. It extends to employment in the broad sense of the word, i.e. including self employment, access to employment, promotion, benefits, work conditions, dismissal, vocational training, promotion, dismissal, educational training, employment advice, involvement in trade unions, etc.; social protection, social advantages, education, access to goods and services available to the public, including housing. ${ }^{19}$ The law consists of different parts, separately regulating labor law, ${ }^{20}$ and modifying contract law. $^{21}$

As to employment it is to be noted that sheltered workshops are not included, the draft only refers to traditional labor relations. The definition of discrimination corresponds to the definitions in the Directives. Direct, indirect discrimination, harassment and instruction to discriminate are included. Exceptions that the EU Directives allow are also granted in the implementing law. Indirect discrimination does not occur in case of a different treatment, if objective reasons justify it. There is an express exception granted to religious organizations, where belief might be a determinative factor, ${ }^{22}$ and special exceptions are allowed on the basis of age. ${ }^{23}$ Once a violation occurred, the employer has to compensate for material and immaterial damages. ${ }^{24}$ Similarly to the previous solution, these also have to be paid in case the person having been discriminated against also has a right to compensation in cases he would not have been employed even if discrimination had not occurred. As opposed to the first draft, victimization is only mentioned in labor relations, but not in reference to general civil law. It has been pointed out that this is not necessarily a detriment, since most cases of victimization seem to be covered by the general rules of contract law, and in some cases even criminal law protection is granted. ${ }^{25}$

${ }^{19}$ Article 2 Section (1) Points 1-8. AGG.

${ }^{20}$ Abschnitt 2, Schutz der Beschäftigten vor Benachteiligung.

${ }^{21}$ Abschnitt 3, Schutz vor Benachteiligung im Zivilrechtsverkehr.

${ }^{22}$ Article 9 AGG.

${ }^{23}$ Article 10 AGG.

${ }^{24}$ Article 15 AGG.

${ }^{25}$ Mahlmann, M.: Prospects of German Antidiscrimination Law. Transnational Law and Contemporary Problems, 2005. 1045. 
The second part of the Act on general contract law invoked more criticisms. This is the field where German legislation went far beyond than what is required by EU law, which only obliges Member States to respect the principle of non-discrimination as regards sex, race and ethnic origin in this field. Nevertheless, the German legislator extended the protection to contract law to persons having other characteristics listed in the Framework Directive. However, this protection of persons having the protected characteristics only applies to such contracts that are typically concluded with a large number of partners in large number of cases of comparable nature (Massengeschäfte, mass businesses), and where the identity of the contractual partner is of minor importance. ${ }^{26}$ This formulation seems to exclude the much debated topic of housing, unless a company or a private person is involved in the business of renting flats, apartments, houses or hotel rooms. To make it more explicit, due to the public outcry and the opposition from the legal profession concerning housing, a specific exception has been granted for cases where there is a special relation and trust between the parties. As to the grounds listed in the Framework Directive including disability this exception is permissible, however as to race and ethnic origin, the exception is clearly in violation of the Race Directive. The only provision that could save the German clause is in Recital 3 Race Directive stating that it is ,also important, in the context of the access to and provision of goods and services, to respect the protection of private and family life and transactions carried out", however in the actual body of the law such reference cannot be found; according to Article 3 the Directive applies to "all persons, as regards both the public and private sectors, including public bodies". The EU legislator could have opted for inserting an exception into the provision on the scope of the Directive, if intended to do so, just like in the case of the Gender Goods and Services Directive, which is according to its Article 3 only applicable to persons providing goods and services available to the public, "and which are offered outside the area of private and family life." The drafters of the Race Directive in contrast did not grant any such exceptions in the actual body of the law, therefore the German law's respective provision seems to be in violation of the acquis communautaire. As it has been shown, it is also against common sense and basic morals, since strictly interpreted, it would allow for the hanging of a sign "Rooms for rent - except for Jews", if the person letting the room lived in the same house, ${ }^{27}$ although it would certainly contradict the general clauses of the BGB.

${ }^{26}$ Article 20 AGG.

${ }^{27}$ Mahlmann: op. cit. 1045. 
Partly as a result of compromise, a number of other exceptions are granted in the second and final version, too. First, contracts in the field of family law are exempted. Second, an objective reason may justify differentiation on the grounds of religion, belief, disability, age, sexual identity or sex. ${ }^{28}$ Third, the prevention of dangers and damages may justify difference in treatment. Fourth, the protection of privacy or intimacy may be a ground for justifiable differentiation. Fifth, special advantages may be granted to groups of persons, if the interest to enforce equal treatment is lacking. Sixth, religious communities may attach importance to the belief of individuals. Seventh, insurance companies are exempted from the scope of the law as well, in case if the protected characteristic is a determining factor as to the subject of the contract and it is underpinned by statistical data. (However, just like in the first draft, pregnancy-related concerns cannot justify different treatment. $)^{29}$

The procedural rules have not been amended as compared to the previous bill; they are taken over from the Directives. The Act expressly states that rules on the representation of disabled persons, i.e. Article 63 SGB IX are not effected. ${ }^{30}$ A novelty is the establishment of the Federal Anti-Discrimination Agency (Antidiskriminierungsstelle des Bundes) functioning at the Federal Ministry for Family Affairs, Senior Citizens, Women and Youth. ${ }^{31}$ The Bundespräsident(in) appoints the person directing the Agency at the suggestion of the federal government. ${ }^{32}$ The Agency receives complaints, supports persons submitting complaints, assists counseling by other bodies, promotes mediation, takes measures of prevention, every four years reports to the federal government and the Bundestag and makes recommendations. ${ }^{33}$ The Agency has to enter into dialogue with NGOs and other responsible bodies, and in order to promote this cooperation it has to create an advisory body of independent experts in the field. ${ }^{34}$

According to a later draft the unified anti-discrimination code would have been called "Act on the Implementation of European Directives for the Realization of the Principle of Equal Treatment" (Gesetz zur Umsetzung europäischer

${ }^{28}$ Article 21 of the bill.

${ }^{29}$ Article 21 Points $1-5$. of the bill.

${ }^{30}$ Article 25 Section (5) of the bill; also see the explanatory note attached to the provision.

${ }^{31}$ Article 26 of the bill.

${ }^{32}$ Article 27 of the bill.

${ }^{33}$ Article 28 of the bill.

${ }^{34}$ Articles $30-31$ of the bill. 
Richtlinien zur Verwirklichung des Grundsatzes der Gleichbehandlung). In Article 1 one could have found the actual Act on the Protection against discrimination. (Allgemeines Gleichbehandlungsgesetz), Article 2 would have contained the Act on the Protection of Soldiers against Discrimination (Gesetz zum Schutz der Soldatinnen und Soldaten vor Diskriminierungen), Article 3 had modified a number of other laws and Article 4 disposed of the entry into force.

The final version came into being with the title General Equal Treatment Act (Allgemeine Gleichbehandlungsgesetz, $A G G$ ) and has been adopted simoultaneously with the separate law on anti-discrimination of soldiers. (Gesetz zum Schutz der Soldatinnen und Soldaten vor Diskriminierung, SADG) The legislator opted for the word "Benachteiligung" (disadvantaging) instead of "Diskrimination" (discrimination) in order to emphasize that not all kinds of different treatment are of a discriminatory character. The exemption of churches has been extended, ${ }^{35}$ victims of discrimination can sue within three months from the point in time they got to know about the discrimination; the victim of discrimination cannot claim from the court that a contract shall be concluded with him or her (no Kontrahierungszwang); in contrast to the previous draft, victims cannot assign their pecuniary claims for damages to NGOs, and NGOs may not represent cases independently from the victim.

The first reading of the bill should have taken place on May 19, 2006, but it has been postponed to June, 2006. Finally, it has been adopted on 14 August 2006, and entered into force four days later.

\section{Political Debate around Implementation}

Previous comments and the heated debate indicated from early on that it will be difficult to reach a compromise. The draft law for the implementation of EU anti-discrimination provisions has been called an "attempt against the basics of the republic." ${ }^{36}$ Volker Kauder, then CDU/CSU (Christian Democratic Union of Germany/Christian Social Union) federal faction whip formulated this objection even more explicitly: "Previously we have been told, it depends on the 'proper race'. Later, in the GDR the 'proper class' has been propagated, later

\footnotetext{
${ }^{35}$ Religious organizations irrespectively of their legal form and facilities associated with them may discriminate on the basis of religion. Article 9 of the new bill.

36 “Anschlag auf die Grundzüge dieser Republikcc. Quoted from Forum gegen Rassismus, Arbeitsgruppe Gleichbehandlung, Info-Brief Nr. 6 März 2005. Bundesministerium des Innern, Ref. IS 3.
} 
it has been a matter of the proper skin color. 'And now we experience: one has to take the proper political stand'. Should this not help, an anti-discrimination law will be drafted." ${ }^{37}$ Many others expressed their worries that the law "desires in its regulating furor, to replace the free individual with the 'good' one", ${ }^{38}$ i.e. that government will be transformed into a moral enforcing agent suppressing liberty and diversity. ${ }^{39}$

In this particular case freedom of private employers, churches, landlords were confronted with the equality of those who are having one or more of the characteristics listed in the Directives. Private employers criticized the bill as one limiting private autonomy. Churches, particularly the Christian ones expressed their worries that they cannot exclude persons in the future who would contradict their teachings, if they had at the same time a protected characteristic.

Some voice bureaucratization concerns, saying that as a result of the reversal of the burden of proof, all sellers and service providers will have to store evidence to show that they have not discriminated against potential buyers, consumers. Other criticisms refer to the difficulties in differentiating between permissible and prohibited differentiations, the additional burden on the judiciary as a result of the flood of anti-discrimination cases, the irrational limitation of the market economy, and preference for certain minorities over family and children.

Mainly small- and middle-size companies voiced their worries about unnecessary bureaucratization, which is understandable since recording and storing evidence for a potential later case might be a disproportionate burden on them. Another reason for the silence of multinational companies is that most of them already adopted anti-discrimination programs following the international trend.

The forces favoring the law are lobby groups and entities of civil society pushing for the rights of women or disabled people. In the political arena the

\footnotetext{
37 "Früher hätten die einen gesagt, es komme auf die 'richtige Rasse' an. Später in der DDR sei die 'richtige Klasse' propagiert worden, dann sei es um die richtige Hautfarbe gegangen. 'Und jetzt erleben wir: Es muss einer die korrekte politische Einstellung haben.' Wenn das nicht helfe, werde ein Antidiskriminierungsgesetz gemacht." Forum gegen Rassismus, Arbeitsgruppe Gleichbehandlung, Info-Brief Nr. 6 März 2005. Bundesministerium des Innern, Ref. IS 5.

${ }^{38}$ Picker: op. cit. 784.

${ }^{39}$ E.g. Adomeit, K.: Diskriminierung - Inflation eines. Begriffs. Neue juristische. Wochenschrift, 2002. 1622-1623, Ladeur: op. cit.
} 
drafters, i.e. the green party and the social democrats pushed for the adoption of the law. They emphasized that the ease of the burden of proof existed for 25 years in Article 611 a) BGB in relation to gender-based discrimination. They also stressed the responsibility of Germany as a Member State to implement the Directives that the Germans also voted in favor of.

It has also been pointed out that it was embarrassing to ask prospective Member States to comply with human rights and to adjust their legal systems according to the acquis communautaire, whereas a founding Member State does not respect its obligations under EC law in the filed of anti-discrimination.

According to some observers the reason for the failure of the Directives' implementation can be explained by the fact that civil society has not been loud enough, as NGOs traditionally pursuing strong lobbying activities in the field of human rights did not doubt that implementation will occur. ${ }^{40}$

\section{Theoretical Debate around Implementation}

\subsection{Hierarchy of Equality}

The German law implementing the four anti-discrimination-related EU Directives reject the hierarchy of equality that is typical for the acquis communautaire, i.e. the national law rejects the idea of the diverse levels of protection and the different scope of application of the anti-discrimination Directives.

The uniform domestic rules resulted in difficulties and prevented the implementing law from adoption for a long time. The protection of disability and other grounds in the Framework Directive have been elevated to the level of protection the Race Directive granted for race and ethnic origin. Apart from an eagerness and ambition of post-World-War-II Germany to be the leading Member State when it comes to the protection of human rights, there might be some constitutional considerations behind the common regulation.

According to a constitutional principle one cannot differentiate between the protected grounds laid down in Article 3 Section (3) Basic Law. Accordingly the legislator is obliged to find a common solution. Disability might however be an exception to this principle, since the Basic Law only prohibits negative differentiation of disabled persons, however does not mention the prohibition of favoring them, as in case of the other protected grounds.

${ }^{40}$ Ibid. 
In spite of the constitutional obligation to treat all persons with any protected characteristic the same way and to grant them the same rights, laws do differ on a lower level, since equality of persons with certain characteristics need legislation of different nature than others. In order for the laws to be effective, the reasons for differentiation have to be identified, and they have to be overcome in suitable ways. Whereas it is almost impossible to find any possible scenario where direct age discrimination may be justified, ${ }^{41}$ differentiation on the basis of disability might be legitimate in a number of cases, like the protection of consumers, fellow employees, just to mention a few.

The advantage of the absence of a hierarchy of equality is that the victim of discrimination does not have to search for his or her most protected characteristic to win a case. Human beings fall into different subgroups at the same time: they are men or women, hetero- or homosexuals, religious or non-religious persons, young or old, disabled or able-bodied and-minded. As Susanne Baer pointed out, everyone who has been discriminated against shall be able to make a case irrespectively of the grounds on the basis of which the victim has been disadvantaged. ${ }^{42}$

\subsection{Drittwirkung}

Based on Article 1 Section (3) Basic Law fundamental rights apply in the relation of the individual versus the state. As opposed to this verticality, Drittwirkung, or the third party effect doctrine would mean that the fundamental rights of a constitution, in this case the Basic Law are applicable in horizontal, i.e. private relations. A direct third party effect (unmittelbare Drittwirkung) has not been foreseen by the Basic Law. The arguments against it are manifold. First, denial of horizontal effect can be derived from the text of the above mentioned Article 1 Section (3), which expressly states that the Basic Law's fundamental rights "bind the legislature, the executive, and the judiciary as directly enforceable law." Second, as Hermann von Mangoldt, then representative of Parliament pointed out, the drafters of the Basic Law

\footnotetext{
${ }^{41}$ It is possible to think of many indirect age discrimination cases; for example when a certain physical strength is necessitated for the job, aged persons may be excluded; in contrast if the position requires experience, this may lead to the screening out of young applicants.

${ }^{42}$ Baer, S.: Kultur am Sonntagmorgen: EU als Gesetzgeber, Antidiskriminierungsgesetzgebung und europäische Rechtskultur, aired on radio Deutschlandfunk, at 9:30 a.m. on September 11, 2005. (Audio record on file with author.)
} 
intended to guarantee basic rights in the classical sense, i.e. the founders of the constitution wanted to "regulate the relation between the individual and the state by setting limits to the exercise of state power, so that humans' dignity remains inviolable." 43 Third, following a systemic interpretation, one can find certain provision in the Basic Law that expressly extend to horizontal agreements, therefore one can conclude a contrario that in all cases there is no such extension in scope, the provision in question, i.e. the majority of fundamental rights does not apply in private relations. ${ }^{44}$ Fourth, when engaging into a teleological interpretation, one cannot assume that the primary aim of the Basic Law is to limit the freedoms of private persons, which would be the result of a general direct third party effect. ${ }^{45}$

As it has been shown, vertical effect of fundamental rights is not subject to dispute, Article 3 Section (3) [2] Basic Law on the prohibition of discrimination based on disability is directly binding on the legislative, executive, and judicial powers. However it is also applicable in private relations, though to a limited extent. Although basic rights do not have a direct third party effect, they are applicable in private relations through the indirect (mittelbare) Drittwirkung doctrine.

The underlying idea behind the general applicability of rights can also be derived from the Basic Law itself. According to Article 1 Section (2) human rights are "the basis of every community, of peace and of justice in the world." The third party effect is also justified by the argument that in contemporary societies it is not only the state that may abuse power and restrict the rights of individuals, but employers, economic entities may also do so. ${ }^{46}$ Therefore

43 „Vielmehr sahen die Beteiligten ihre Aufgabe darin, die Grundrechte im Sinne der alten klassischen Grundrechte zu gestalten. [...] In den Grundrechten sollte also das Verhältnis des Einzelnen zum Staate geregelt werden, der Allmacht des Staates Schranken gesetzt werden, damit der Mensch in seiner Würde wieder anerkannt werde." Parlamentarischer Rat, Bonn 1948/49, Annex to the stenographic report of the May 9. 1949 session. Written memorandum of Dr. von Mangoldt on Part I on Basic Rights. Reproduced at http://www.gewaltenteilung.de/grundrechte.htm.

${ }^{44}$ Such as Article 9 Section (3) for example, banning private agreements impairing the right to form associations to safeguard and improve working and economic conditions.

${ }^{45}$ Pierroth, B.-Schlink, B.: Grundrechte. Staatsrecht II. Heidelberg, 2005. 44, Rn. 174-175.

${ }^{46}$ Ibid. 176. 
private entities that may also stand in vertical power relation to individuals, shall not be exempted from basic rights scrutiny. ${ }^{47}$

The justification of the original fear behind the concept of vertical effect, i.e. that the state is likely to abuse power to the detriment of individuals, has also been called into question. Through social and economic rights the state has been burdened by positive obligations, and it has to provide appropriate procedures and resources for the realization of these rights. Freedom, as German scholar Ulrich Preuß put it "does not only imply freedom from the state but also requires institutional devices that allow the realization of freedom through the state." 48 (emphasis in original) As the vertical nature of private relations, such as those between employers and employees, and the state support systems show, the lines between horizontal and vertical Drittwirkung are blurred, especially in the German Federal Republic, where the constitution guarantees that Germany be a social state. ${ }^{49}$

The German Federal Constitutional Court dealt with the fundamental issue of third party effect in a very early case carving out the borders of free speech. ${ }^{50}$ In the Lüth case the Court first emphasized the objective order of values in the Basic Law centering upon dignity and the free development of personality influencing all fields of law, be it public or private. The Court then rejected an unlimited horizontal application of fundamental rights in private relations propagated in earlier cases by the Federal Labor Court, but held that "[t]he legal content of basic rights as objective norms is developed within private law through the medium of the legal provisions directly applicable to this area of the law. [...] A dispute between private individuals concerning rights and duties emanating from provisions of private law-provisions influenced by the basic rights-remains substantively and procedurally a private law dispute [...] The influence of the scale of values of the basic rights affects particularly those provisions of private law that contain mandatory rules of law and thus form part of the ordre public [...] In bringing this influence to bear, the courts may invoke the general clauses which, like Article 826 of the Civil Code, refer to standards outside private law. "Good morals" is one such

\footnotetext{
${ }^{47}$ Sommeregger, G.: The Horizontalization of Equality, in Sajó, A.-Uitz, R. (Eds.): The Constitution in Private Relations: Expanding Constitutionalism, Utrecht, 2005. 41.

${ }^{48}$ Preuß, U.: The German Drittwirkung Doctrine, in Sajó-Uitz (Eds.): op. cit. 29.

${ }^{49}$ Article 20 Section (1) Basic Law: ,The Federal Republic of Germany is a democratic and social federal state." This provision is even protected by the Article 79 Section (3), the eternity clause of the Basic Law, i.e. it cannot be amended.

${ }^{50}$ Lüth Case, 7 BVerfGE 198 (1958).
} 
standard." ${ }^{51}$ Ultimately courts, i.e. public institutions are deciding private disputes. The judicial power, together with the executive and the legislative, is directly bound by basic rights as declared by Article 1 Section (3) Basic Law. The German Federal Constitutional Court concluded that courts deciding on private law matters have to interpret civil law in line with fundamental rights.

Basic rights do not directly effect private relations, but certainly influence them. The rights contained in the Basic Law do not solve civil law disputes concretely, but find complete expression through the rules dominating the given branch of law. ${ }^{52}$ Like basic rights in general, Article 3 (3) [2] also radiates through an indirect third party effect (Drittwirkung) into private relations through the civil law's general clauses (Generalklauseln). ${ }^{53}$ These are contained among others in Article 826 of the German Civil Code (Bürgerliches Gesetzbuch, $B G B)^{54}$ and refer to the concept of good faith, public morals, public order (sittenwidrige vorsätzliche Schädigung). Courts interpret these clauses in light and in conformity with fundamental righs. According to their historical understanding, industrial societies set the conditions for freedom and equality, which presuppose a factual symmetry, according to which all persons have the same rights to act according to their interests and to enforce these. ${ }^{55}$ This factual symmetry is today compromised by both the state and by private entities. The Basic Law itself establishes an imbalance when protecting property and the right to conclude contracts; further the legislative power is entitled to construct asymmetric relations, as long as privileges are not created and some persons are not placed in a helpless or defenseless situation. ${ }^{56}$

The notion of third party effect, Drittwirkung, is at the center of the German debate preventing the anti-discrimination law from being adopted. Many German legal scholars argue that there should be a differentiation between prosecution of discrimination in the public arena and intrusion into private relations. It has been contended that the new law extensively regulating the private sphere is unconstitutional, foreign to the liberal tradition of the BGB and against common sense. ${ }^{57}$ Some see the enforcement of equality as the limitation of private

${ }^{51}$ Translation is cited from Kommers, D. P.: The Constitutional Jurisprudence of the Federal Republic of Germany. Durham and London, 1997. 363.

${ }^{52}$ Pierroth-Schlink: op. cit. 181.

${ }^{53}$ Heun, W. in Dreier, H. (ed.): Grundgesetz, Vol. I, Tübingen, 2000. Article 3. Rn. 123.

${ }^{54}$ See also Articles 138 on contracts contra bonos mores and 249 BGB on Treu und Glauben, i.e. bona fide.

${ }^{55}$ Heun: op. cit. Article 3. Rn. 139.

${ }^{56}$ Pierroth-Schlink: op. cit. 183.

${ }^{57}$ E.g. Ladeur: op. cit. 
autonomy by curtailing the general liberty to choose. ${ }^{58}$ They contend that autonomous choice, a possibility to distinguish without any justification or reasoning, according to one's irrational choice or taste, is the basis of private law, which has now been curtailed. Others see the law as the peak of a continuous development of German law since the World War II. They emphasize that the law does not intend to prohibit discriminatory thoughts, but only discriminatory actions. ${ }^{59}$

Whereas in the previous discussion of the notion of third party effect, I dealt with the role of the judiciary, anti-discrimination laws raise a different problem. It is the legislative power that prescribes the horizontal application of Drittwirkung obligatory. Therefore some writers differentiate between three kinds of horizontalities: direct horizontality, indirect third party effect, and Drittwirkung prescribed by the legislative. ${ }^{60}$

At the heart of the German debate on Drittwirkung is a provision of the Race Directive. According to Article 3 Section (1) h) „Within the limits of the powers conferred upon the Community, [the Race] Directive shall apply to all persons, as regards, both the public and private sectors, including public bodies, in relation to [...] access to and supply of goods and services which are available to the public, including housing." The reference to supply of goods and services offered to the public are missing from the Framework Directive. Nevertheless the German Act extends the protection of all protected groups having the characteristics listed in both the Race Directive and the Framework Directive to goods and services offered to the public and housing. It should also be noted at the same time that the interpretation of the term 'offered to the public' is left to the Member States. Of course not all offers to the public can be meant. A repeatedly invoked example is the newspaper advertisement listing the desired characteristics of the preferred future partner. ${ }^{61}$ In such a personal issue legal prohibition of discrimination against persons with certain-

${ }^{58}$ Sommeregger, G.: The Horizontalization of Equality, in Sajó-Uitz (Eds.): op. cit. 46.

${ }^{59}$ Winkler, V.: The Planned German Anti-Discrimination Act: Legal Vandalism? A Response to Karl-Heinz Ladeur. German Law Journal, 2002. Winkler rejects all three assumption by Ladeur, i.e. that the draft was unconstitutional, against common sense and also opposes the deeply rooted belief that the BGB was liberal. He thinks its a myth since Gertrude Lübbe-Wolff first said so in her writing: Die Grundrechte als Abwehrrechte. Baden-Baden, 1988.

${ }^{60}$ Sommeregger: op. cit. 34.

${ }^{61}$ Schöbener, B.-Stork, F.: Anti-Diskriminierungsregelungen der Europäischen Union im Zivilrecht - zur Bedeutung der Vertragsfreiheit und des Rechts auf Privatleben, Zeitschrift für Europarechtliche Studien, 2004. 60. 
even protected-characteristics would be contrary to common sense. It is a widely accepted principle that the more a law intrudes into the private sphere, the more flexible it should be towards arbitrary differential treatment. ${ }^{62}$ In line with the principle, private and family relations are currently not covered. Recital 4 of the Race Directive reinforces that "[i]t is important to respect such fundamental rights and freedoms, including the right to freedom of association. It is also important, in the context of the access to and provision of goods and services, to respect the protection of private and family life and transactions carried out in this context." Many contend however that contractual freedom in general, and not only in the very intimate sphere would be impaired and be against common sense, once screened though anti-discrimination laws.

\subsection{Freedom versus Equality}

There have been some attempts to compare the Directives to the common constitutional traditions of the Member States instead to submit them to national scrutiny. Affected rights of potentially discriminating persons, respected by the European Court of Justice (hereinafter referred to as: ECJ) have been identified. The two main rights are the right to property and contractual freedom, and the right to private life, privacy. Article 16 of the not yet binding Charter of Fundamental Rights, the case-law of the ECJ ${ }^{63}$ the right to conclude contracts as derived from Article 1 Protocol 1 ECHR on the right to property have been invoked in relation to the former. As to the latter aspect, Article 7 of the Charter of Fundamental Rights, the case-law of the ECJ ${ }^{64}$ and Article 8 ECHR have been named. Authors arrived to the same conclusion that has also been reached in the evaluation of the Act on the basis of already existing national laws: elevation of equality cannot mean the reduction of freedom of others, since in a situation the law tries to prevent, the person having specific characteristics would be pushed out of the market. They would remain unprotected and would only have a formal declaration to a right to conclude contracts. ${ }^{65}$ Furthermore it shall be borne in mind that the ECJ also protects equality as a general principle of law, not only freedom of contract and private life. Articles 20 and

\footnotetext{
${ }^{62}$ Ibid. 66.

${ }^{63}$ Advocate General Geelhoed in Case C-334/00 Tacconi [2002] ECR I-7357.

${ }^{64}$ Case C-62/90 Commission v Germany [1992] ECR I-2575; Case C-404/92 X. v Commission [1994] ECR I-4737.

${ }^{65}$ Schöbener-Stork: op. cit. 61.
} 
21 of the Charter of Fundamental Rights on general equality and equality before the law, Articles 22-25 of the Charter on cultural rights, equality between men and women, rights of children, of the elderly, and of persons with disability, Article 13 EC Treaty, Article 14 ECHR, or Article 1 of Protocol 12 ECHR can be named. Elevated to this level, a collision of general principles of laws can be declared.

Freedom, mostly freedom of contract and equality are opposed also in the German debate. ${ }^{66}$ This is an old controversy that comes up from time to time in Germany in many fields. As it has been pointed out in the framework of constitutional law, the political demand to ensure as wide societal freedom as possible collides with the wish to ensure as much equality as possible. Societal freedom is freedom of the strong, whereas societal equality is the equality of the weak. As opposed to the social constriction of the conflict, the constitutional protection of these two values peacefully cotton. The constitutional provisions protecting equality and freedom leave a wide margin of appreciation to the legislative power by only setting the borders. ${ }^{67}$

The legislative previously used to ensure equality before the law, equality in relation to the state and the individual, and equality in private relations through the general clauses of the BGB. It was up to the judge to fill the general clauses and interpret them in light of fundamental rights. Through the adoption of anti-discrimination legislation the room left to the judiciary shrank and the legislative determines-and takes political responsibility-for the moral choices the judiciary used to make. The judge may still enter into a kind of balancing, but the major outline of the equality approach in private relations is set by the legislative.

This solution is not entirely unknown to the German legal system. At a lower level of norms, the issue comes up in labor law around the employers' obligation to treat all workers equally (arbeitsrechtliche Gleichbehandlungsgrundsatz). ${ }^{68}$ Whereas previously equal treatment has been justified by the community bonds between employer and employees, modern reasoning is closer to the roots of non-discrimination law. According to the more recent theory,

\footnotetext{
${ }^{66}$ Loenen, T.-Rodrigues, P. R. (Eds.): Non-discrimination Law: Comparative Perspectives. The Hague, 1999.

${ }^{67}$ Pierroth-Schlink: op. cit. 430.

${ }^{68}$ Schiek, D.: Torn between Arithmetic and Substantive Equality? Perspectives on Equality in German Labour Law. The International Journal of Comparative Labour Law and Industrial Relations, 2002. 153-154.; Schiek, D.: Differenzierte Gerechtigkeit: Diskriminierungsschutz und Vertragsrecht. Baden-Baden, 2000.
} 
the contractual employment relationship is typically long-term, in many cases the parties conclude the contract for indefinite time. Since it is impossible to regulate all kinds of possible future disputes in a casuistic way, at least the basic principles have to be set. "If there is some collective order, it is held that this order must correspond to a standard of equality to be just." ${ }^{\text {"99 }}$ It seems that this theory mirrors a social contract theory applying it to a smaller community.

As Susanne Baer showed it, "Whenever freedom is not seen in an isolated way, but in relation to other basic rights, one inevitably comes to the conclusion that no basic rights can grant empowerment for the discriminatory use of freedom. The unity of the constitution commands rather to make freedom in equality possible, as a realization of human dignity." that freedom is only freedom of those who are treated equally. ${ }^{71}$ Disabled, who have no chance to access buildings so as to participate at a job interview, just like foreigners not served in restaurants, or potential tenants with dark skin colors have solely theoretical, but no real freedom of contract. The full realization of equality understood this way is a costly means of realizing nondiscrimination. As people are inherently different, equal freedom will never be achieved, but the starting points could be equalized. However, ensuring even this understanding of equality may be burdensome in two ways. First, the realization of equality in the access to goods and services may drive a seller out of the market, if majority customers punish him for his non-discriminating behavior. If however the principle of non-discrimination extends to all sellers and service providers, the racist/sexist/etc. consumers will have no chance to boycott non-discriminating companies. ${ }^{72}$ Second, direct costs occur when it

${ }^{69}$ Schiek: Torn between Arithmetic and Substantive Equality? op. cit. 153-156.

70 "Wer Freiheit nicht isoliert, sondern im Zusammenhang mit anderen Grundrechten denkt, kommt zwangsläufig zu dem Schluss, dass kein Grundrecht dazu ermächtigen kann, Freiheit diskriminierend zu nutzen. Die Einheit der Verfassung gebietet es vielmehr, Freiheit in Gleichheit als Verwirklichung der Menschenwürde zu ermöglichen." Baer, S.: 'Ende der Privatautonomie' oder grundrechtlich fundierte Rechtsetzung? Zur deutschen Debatte um Antidiskriminierungsrecht, Zeitschrift für Rechtspolitik, 2002. 290-294.

${ }^{71}$ Schöbener-Stork: op. cit. 61., also shared by Winkler in Winkler: op. cit. paragraph 10 .

${ }^{72}$ At a different level, the equalization of starting points had also been considered at the beginning of European integration. Article 141 EC Treaty (ex Article 119) states the principle of equal pay for equal work irrespective of gender. This is the oldest nondiscrimination principle of EC law, which has been inserted into the Treaty of Rome upon the initiation of the French. France feared that its laws on equal pay for men and women will put them at a competitive disadvantage. If however all member States comply with the 
comes to accommodation, be it the accommodation of religion or disability. The issue of allocation of these costs among the state, private parties and the disabled persons themselves shall be addressed.

Coming back to the anti-discrimination legislation, the first version of the extensive law implementing the relevant EU Directives received many criticisms and resulted in harsh opposition. It has been argued on the theoretical level that freedom-based systems are necessarily inherently discriminatory, and exception to freedom can only be granted to this in case of serious grievances, like in case of contracts that are against the public order. This problem however is said to be solved through the general clauses of the BGB. ${ }^{73}$

The solution of the modified bill can be regarded as a compromise. Total prohibition of discrimination applies only for "mass businesses" ("Massengeschäfte"). A special issue dominating the discussion in Germany is whether landlords may discriminate when renting a flat or a room. Again a compromise has been reached. Whenever a house, flat or room is to be rented or sold where the owner him- or herself is also living, one cannot speak of an offer to the public. Renting a room to someone with whom the landlord will live together or selling a part of the seller's house if he or she is going to stay in the other part of the building involves a part of private life, where law cannot enter. ${ }^{74}$

Some referred to freedom of contract as follows from the free development of personality laid down in Article 2 Section (1) Basic Law. It is however contested whether national basic rights as laid down in the domestic constitution, serve as a proper test for the limits of implementation of an EU law.

\section{Legal Consequences of Non-Implementation}

The European Commission filed a suit with the ECJ against Germany for the non-implementation of the Race and Framework Directives. The ECJ declared in its decisions C-329/04 of April 28, 2005 and C-43/05 of February 23, 2006 that, by failing to adopt, within the prescribed period, the laws necessary to comply with the Race and Framework Directives, Germany has failed to fulfill its obligations under EC law.

principle, France will not suffer such detriments. Barnard, C.: EC Employment Law, Oxford, 2000. 198.

${ }^{73}$ Picker: op. cit. $771-784,782$.

${ }^{74}$ Schöbener-Stork: op. cit. 77. 
According to the principle of supremacy of EU law, the acquis communautaire has primacy over the national law of the Member States. The principle ,lex posterior derogat lege priori" does not apply in case of a conflict between the acquis and national law, since it would undermine EU law. Although there is no Treaty reference to this principle, ${ }^{75}$ the answer is clear, the primacy of EU law has been established by the early case-law of the European Court of Justice. $^{76}$ The ECJ reestablished the principle of supremacy of Community law, and held that the only court that can invalidate EU laws is the ECJ. ${ }^{77}$ In relation to the non-implemented Directive the question emerges whether German courts or parties can rely directly on the Directives in lack of an implementing national law, i.e. whether a person who feels to have been discriminated against may invoke the Directive directly, if a Member State has not (or not fully) implemented it.

There are major differences as to the direct effect of Treaty provisions, Regulations and Directives. Whereas primary sources of Community law and Regulations can be relied on directly in national proceedings, the situation of Directives is more complicated. Following from the nature of the Directive, as opposed to Regulations and decisions, the EC Treaty in its Article 249 prescribes for national implementation of Directives. Directives are the main ,instruments of harmonization" ${ }^{, 78}$, they are binding as the result to be achieved, however the form and choice of methods to achieve the objective are left to Member States.

The criteria of direct effect of Directives has been established by the caselaw of the ECJ. The first is a general rule: any part of the acquis communautaire can only be relied on directly, if it is clear, precise and unconditional. ${ }^{79}$ Following from their nature, Directives are not that detailed and precise, often the ambiguous language is the result of a political compromise, and national peculiarities can be taken into account in the process of implementation. In the

${ }^{75}$ In the Constitutional Treaty of the European Union this question would be solved. Article I-10 Section (1) of the draft Treaty by codifying existing case-law provides that the "Constitution, and law made by the Union's Institutions in exercising competences conferred on it, shall have primacy over the law of the Member States".

${ }^{76}$ Case 26/62 Van Gend en Loos v Administratie der Belastingen [1963] ECR 3, Case 6/64 Costa v E.N.E.L. [1964] ECR 1141.

${ }^{77}$ For further discussion about the supremacy doctrine, see Craig, P.-De Búrca, G.: EU Law: Text, Cases, and Materials, Oxford, 2003. 275-316.

${ }^{78}$ Craig-De Búrca: op. cit. 202.

${ }^{79}$ Case 26/62 Van Gend en Loos v Administratie der Belastingen [1963] ECR 3, Case 6/64 Costa v E.N.E.L. [1964] ECR 1141. 
lead case, Van Duyn, the ECJ held that Directives are binding, as to their effet utile, i.e. their useful effect. ${ }^{80}$ In this way Member States have been precluded from relying on the non-implementation of a Directive in cases initiated according to them by individuals.

Second, in case of Directives, the date for implementation must have been passed. Nevertheless, according to the ECJ's settled case-law, during the period of implementation of a Directive, Member States must refrain from taking measures that are likely hamper the attainment of the result to be achieved by the Directive.

In the case Mangold ${ }^{81}$ the ECJ held that in relation to the compliance with the Framework Directive that it was ,the responsibility of the national court to guarantee the full effectiveness of the general principle of non-discrimination in respect of age, setting aside any provision of national law which may conflict with Community law, even where the period prescribed for transposition of that directive has not yet expired."

Third, Directives, unlike Treaty provisions and Regulations only have vertical direct effect, i.e. they can only be invoked against public entities. The reason for this limitation is that Directives are addressed to the Member States, which are required to implement them into national laws. Since private individuals do not participate or influence that process, it would be unjust to make them responsible for non-implementation of EU Directives. It should however be mentioned that the ECJ has been very generous with the determination of what entity amounts to a public body. ${ }^{82}$ Furthermore, it established the principle of indirect effect. According to the Von Colson principle, domestic courts are obliged to interpret all national laws in the light of the Directives. ${ }^{83}$

Another way victims can make use of the Directive is to invoke the concept of state liability. In case the state's breach of EC law is sufficiently serious, pecuniary compensation can be claimed. The fact that someone asks for compensation does not preclude him or her from relying on the vertical direct effect at the same time. The test for state liability and damages has been phrased

${ }^{80}$ Case 41/74 Van Duyn v Home Office [1974] ECR 1337.

${ }^{81}$ C-144/04 Werner Mangold v Rüdiger Helm [2005] ECR I-9981. Reference for a preliminary ruling from the Labor Court of München.

${ }^{82}$ E.g. Case C-188/89 A. Foster and Others v British Gas plc Office [1990] ECR I3313, where British Gas was regarded as a public entity due to state influence.

${ }^{83}$ Case C-14/83 Von Colson and Kamann v Land Nordrhein-Westfalen [1984] ECR 1891. 
in the in the Francovich case. ${ }^{84}$ The ECJ first established a test for making Member States liable for failure to implement Directives and in later cases refined the requirements.

Recently the Berlin Labor Court in a decision of July 13, $2005^{85}$ relied on the Framework Directive in the case of a disabled applicant who has been rejected by the Berlin police. She received a compensation amounting to a gross six-month-salary at the police. Although she satisfied all criteria necessary and prescribed for the job of supervising parking lots, she has not been employed solely because she had a disability the degree of which was $40 \%$. Although the applicant suffered from serious neurodermitis, she could work previous to her application to the police without any difficulties, and she has not been sick for a single day for the last 8 years before she applied for the job. Since her disability did not reach $50 \%$, and she has not been granted equal status to severely disabled persons, she was not covered by the respective provisions of the Social Code ${ }^{86}$ Since the police is a public, state employer, the Berlin court invoked directly the respective provisions of the Framework Directive.

\section{Conclusion and Predictions on the Future of German Anti- Discrimination Legislation}

A few days before the present essay has been submitted, the German legislator adopted the long-awaited the General Equal Treatment Act, the anti-discrimination law transposing the EU 's equality Directives. The delay in the adoption of the domestic law and the failures of the several drafts were subject to hot debates in the last more than two years.

Susanne Baer explains the failure of the previous anti-discrimination drfats pessimistically by the general attitude of the majority of German citizens. She explains the "dissonance of the Germans in the European orchestra" ${ }^{\text {"87 }}$ with the racist and anti-Semitic attitude of most members of society. Indeed, as the Eurobarometer studies show, ${ }^{88}$ Germans' resistance to multicultural society,

${ }^{84}$ Cases C-6 and 9/90 Francovich and Bonifaci $v$ Italy [1991] ECR I-5357.

${ }^{85} 86$ Ca 24168/04, NZA-RR 2005, 608.

${ }^{86}$ Article 81 Section (2) SGB IX.

${ }^{87}$ Baer: op. cit.

${ }^{88}$ Coenders, M., Lubbers, M. and Scheeper, P.: Majorities' attitudes towards minorities in European Union Member States, Results from the Standard Eurobarometers 1997-2000- 
opposition to civil rights, favoring the repatriation of migrants, is beyond the average. Both East and West-Germans' attitudes are the second or third most negative from among the pre-2004-enlargement Member States towards minorities, depending on the specific minority-related question.

I believe the reasons for the lengthy non-implementation of the EU antidiscrimination Directives are multi-layered. The question is not whether private autonomy may be limited or not, but the extent to which restriction is permitted is at stake. ${ }^{89}$ Equality is a long adopted value by the German legal system and also by society. The principle of equality is not questioned, rather the version of substantive equality is searched that is reconcilable with market considerations. A growing tendency against minorities at societal level is one side of the coin, which is coupled by the fact that German legal theory and tradition extensively elaborated on the concept of third party effect and non-discrimination, so the German drafters took the law implementing the EU Directives seriously.

With a sincere discourse law can change social conceptions more efficiently. Those discriminating either maliciously or without ill will are not faced with these ideas first when the law sanctions them, but can actively participate in the debate and express, develop their views on the matter. Law shapes social constructions not only in the field of equality, but also contractual freedom would be unthinkable without the legally constructed concept of contract. Law has an effect on all citizens irrespectively of whether they know the relevant provisions of the BGB or not. Similarly, equality legislation may add to people's general understanding of non-discrimination. In this sense the debate that evolved around the implementing law is certainly beneficial.

In the German literature sexual orientation, and religion are often mentioned as problematic grounds for non-discrimination in private relation; in contrast disability discrimination and its profit-diminishing aspects are mentioned surprisingly rarely. The reason is most probably that the Framework Directive does not specify a number of concepts: For example the definition of disability, sanctions for non-compliance are left to the Member States. ${ }^{90}$ Therefore the realization of disability rights mainly depends on the Member

2003, Report 2 for the European Monitoring Centre on Racism and Xenophobia, Ref. no. 2003/04/01, http://eumc.eu.int/eumc/material/pub/eurobarometer/EB2005/Report-2.pdf

${ }^{89}$ This is in line with Winkler's remark on the Basic Law: „I cannot see that there is a virgin part of the Constitution in which any kind of unbound, immaculate freedom would rule." Winkler: op. cit. paragraph 8.

${ }^{90}$ The responsibility of Member States has been reinforced in the Case C-13/05 Sonia Chacón Navas v Eurest Colectividades SA of July 11, 2006 in effect leaving the definition of disability up to the Member States. 
States themselves. As it has been shown, the German government did not only intend to implement the EU pieces of law, but wanted to give a way broader protection to traditionally discriminated groups than the Directives prescribed. This approach although benevolent, had theoretical and practical mistakes. Theoretically, it did not take sufficiently account of the fact that there are different reasons behind discrimination of individuals with diverse characteristics that serve as the basis of protected grounds. ${ }^{91}$ It is certainly problematic to regulate the different kinds of mental, physical, psychological impairments together in one instrument, but it is almost impossible to regulate disability together with race, ethnicity, age, sex, sexual orientation, religion and belief, if detailed rules are to be laid down. ${ }^{92}$ Such a common regulation is only imaginable in the form of a single constitutional equality provision, or an EU Directive setting only the objectives and the framework for national legislation. These are sufficiently broad and vague rules for a joint regulation of the different kinds of protected grounds. However, once the details are to be set, it is more advisable to regulate them separately. The practical side of the problem is that a law giving an overbroad protection to persons with diverse characteristics can hardly enjoy the support of all parties adhering to different ideologies. The lack of political consensus led to the fall of the previous draft laws or at least to the Act's hibernation for years. The fact that Germany wanted 'to be more 'European' than 'Europe","93 was not only detrimental to the persons belonging to the groups the anti-discrimination law intended to protect, but Germany was also in violation of EU law for more than two years. At a more positive note however the German legal philosophical and political controversy can serve as an example for Member States which either complied with EU laws without any further legal debate and civil dialogue or even worse, translated the Directives into their official languages and promulgated it in the form of a national piece of legislation.

\footnotetext{
${ }^{91}$ In the German context, three reasons have been differentiated and an economic case has been advocated for anti-discrimination rules in private law by Engert in: Engert, A.: Allied by Surprise? The Economic Case For an Anti-Discrimination Statute. German Law Journal, 2003.

92 This view has also been shared by among others Mahlmann: op. cit. 1045.

${ }^{93}$ Picker: op. cit. 771-784, 775.
} 